\title{
THE EVALUATION OF UNDISCOVERED ARCHEOLOGICAL GEOHERITAGE POTENTIAL - THE CASE OF RUDNA GLAVA SITE (EASTERN SERBIA)
}

\author{
Dobrila LUKIĆ \\ Eighth Belgrade Grammar School, 71 Grčića Milenka St., Belgrade 11000, Serbia, e-mail: dobriladjerdap@gmail.com \\ Marko D. PETROVIĆ* \\ Geographical Institute "Jovan Cvijić”, Serbian Academy of Sciences and Arts, Belgrade, Serbia; \\ South Ural State University, Institute of Sports, Tourism and Service, Russia, e-mail: m.petrovic@ gi.sanu.ac.rs \\ Milan M. RADOVANOVIĆ \\ Geographical Institute "Jovan Cvijić”, Serbian Academy of Sciences and Arts, Belgrade, Serbia; \\ South Ural State University, Institute of Sports, Tourism and Service, Russia, e-mail: m.radovanovic@ gi.sanu.ac.rs
}

\section{Julia A. SYROMIATNIKOVA}

South Ural State University, Institute of Sports, Tourism and Service, Russia, e-mail: syromjatnikowa@mail.ru

\section{Dunja DEMIROVIĆ BAJRAMI}

Geographical Institute "Jovan Cvijić", Serbian Academy of Sciences and Arts, Belgrade, Serbia; South Ural State University, Institute of Sports, Tourism and Service, Russia, e-mail: d.demirovic@ gi.sanu.ac.rs

\begin{abstract}
Citation: Lukić, D., Petrović, M.D., Radovanović, M.M., Syromiatnikova, J.A., \& Demirović Bajrami, D. (2021). THE EVALUATION OF UNDISCOVERED ARCHEOLOGICAL GEOHERITAGE POTENTIAL - THE CASE OF RUDNA GLAVA SITE (EASTERN SERBIA). GeoJournal of Tourism and Geosites, 36(2spl), 654-662. https://doi.org/10.30892/gtg.362spl13-695
\end{abstract}

\begin{abstract}
As one of the oldest documented mines in Europe, Rudna Glava should be at the very top when it comes to geotourist visits in Serbia and the Balkans. The research goal is to point out the possibilities of geotourism development in this part of Serbia, while the findings aim to identify the existing problems for geotourism development in the area. The study will analyze the geotourism potential of this archaeological site by using the Geosite Assessment Model (GAM), combining the main and additional values. The GAM involves grades given by experts and provides a relatively actual image of the geoheritage state based on which it is practicable to plan and enhance the activities for the observed sites. The outcomes showed that the observed site has a high score of the main, and a low score of additional values. This means that the site should be additionally protected, and included in various tourist programs.
\end{abstract}

Key words: geotourism, assessment, GAM, Rudna Glava, Serbia

$* \quad * \quad * \quad * * *$

\section{INTRODUCTION}

Archeological geoheritage, as a unity of the cultural monuments and the corresponding natural environment, is an indicator of paleoecological conditions on the Earth and the people's attitude toward the natural environment. It comprises the settlements and various structures from the prehistory to the Ancient times, as well as the archeometallurgical structures, i.e. old mines and the accompanying ore-processing facilities. In the last decades, the interest of the scientists of different profiles within the geo-sciences has been directed toward creating the inventory of various geoheritage objects and their valorization for the needs of tourism. Scientist from different regions focus their research on the connection between cultural monuments and the natural environment (Kavčič and Peljhan, 2010; Bujok at al., 2015; Goemaere at al., 2015), as well as on the relation of geoheritage and tourism (Endere and Prado, 2014; Ólafsdóttir and Dowling, 2014; Sellier, 2016). Managing the archeological geoheritage and its promotion for tourism purposes is of great importance for its preservation and protection, as well as for the achievement of the appropriate economic effects, employment of the local population, and reconfiguration of the territory it is located on (Lazzarotti, 2003). Greater concentration of archaeological geoheritage objects in one place, i.e. locations in the immediate vicinity of each other, enable joint analysis, which creates an opportunity to strengthen their own values (Ludwikowska-Kedzia and Wiatrak, 2020). It is imperative not only to emphasize their existence, but also to highlight them as possible geotourism resources with their specific archaeological value (Abdelmaksoud, 2020). Geoheritage, as a result of the evolution of the Earth's crust, has outstanding scientific, historical, economic, and aesthetic features (Paungya et al., 2020), and can be an important driver of sustainable development from the point of geotourism (Di Gregorio et al., 2014). Sustainable development does not only refer to activities that protect nature, but also promotes the well-being of the local community. These activities can be carried out through individual tourist visits to geological sites or through guided tours through geotourism routes. The involvement of the local community is reflected through the provision of services of geo-inns, georestaurants and geo-souvenirs, with the support of the local authorities in providing the necessary infrastructure, in order to achieve a development of geotourism destination (Hadian et al., 2021). Geotourism is a form of tourism that maintains and 
enhances the identity of the area, taking into account the geology of the surroundings, culture, aesthetics, heritage and wellbeing of local residents (Matshusa et al., 2021). It is ecologically and culturally responsible tourism, and, at the same time, synergistical, which means that it gathers all the elements of geographical space to create a travel experience that is richer than the sum of its parts and attractive to visitors with different interests (Arora et al., 2020). Geotourism has received its full affirmation within geoparks that serve the preservation of national and geological heritage and are used as local and economic protection. UNESCO has set very high criteria for an area to be included in the global network of geoparks. Geopark management should be such as to eradicate poverty, create jobs for local people and protect the environment (Bhinekawati et al., 2020).

In that context, Rudna Glava, with its potential, should be included in the top ones when it comes to the tourist visits on the territory of the Djerdap UNESCO Global Geopark and eastern Serbia. Many scientists believe that Rudna Glava is the first documented mine not only in Europe, but in the world as well (Jovanović, 1971, 1978, 1982, 1986, 2009; Jovanović and Ottavai, 1976; Borić, 2009; Roberts et al., 2009). The mine was in use in the late sixth and in the first half of the fifth millennium BC, i.e. during the late Neolith, in the times of the Vinča culture, and during the early Eneolithic period. Rudna Glava mine was also occasionally used during the Roman times, in the 4th century. From the Roman times to the Modern ages, the iron ores were exploited from Rudna Glava, and it was the primary ore on this ore deposit, whereas the carbonate copper ore (malachite and azurite) represents the secondary phenomenon (Antonović, 2018). The important fact is that Rudna Glava provides the reconstruction of mining techniques, tools, and processes, and gives a rare insight into the social and symbolic meanings of copper mining in the prehistory. The aim of this paper is to assess the applicability of GAM matrix - the model for determining the tourist potential of Rudna Glava archeological geoheritage object in the context of geoheritage management and geotourism development so that this site could attract more visitors

\section{THE OBSERVED CASE STUDY: RUDNA GLAVA SITE}

The region of eastern Serbia, including the border regions of the Carpathians and the Balkans, is characterised by a complex geological structure with eruptive rocks in the central part. Different rocks, according to their origin, such as igneous, sedimentary, and metamorphic, were formed in different periods of the geological history of the Earth, from Paleozoic to Quaternary. They are related to different geomorphologic forms. On the west, there are calcareous ridges of Veliki Greben, Liškovac and the Homoljske Planine Mountains, and Veliki Krš, Kučaj, and Veliki Maljenik, between which lies Crni Vrh of volcanic origin. Southeast and south of the calcareous zone of the eastern Serbia, there are volcanic massifs of Rtanj and Tupižnica Mountains which are mostly composed of andesite. In the southeast is Stara Planina Mountain composed of granite, and Deli Jovan, with the zones of gabbros in the northeast. Here we will mention only the most important metallogenic zones in eastern Serbia that are rich in gold, silver, copper, iron, and lead ores, and which are exploited even today. They are primarily the zone of Bor, with the deposits of copper and gold, and the zone of Poreč Stara Planina, with the deposit of magnetite (Rudna Glava) and gold quartz trails, and finally, the zone of the Homoljske Planine Mountains - Beljanica, with its quartz trails which contain gold and tungsten. There are also secondary deposits of gold in the valleys of the rivers Pek, Crni Timok and Beli Timok, and their tributaries (Petković, 2009).

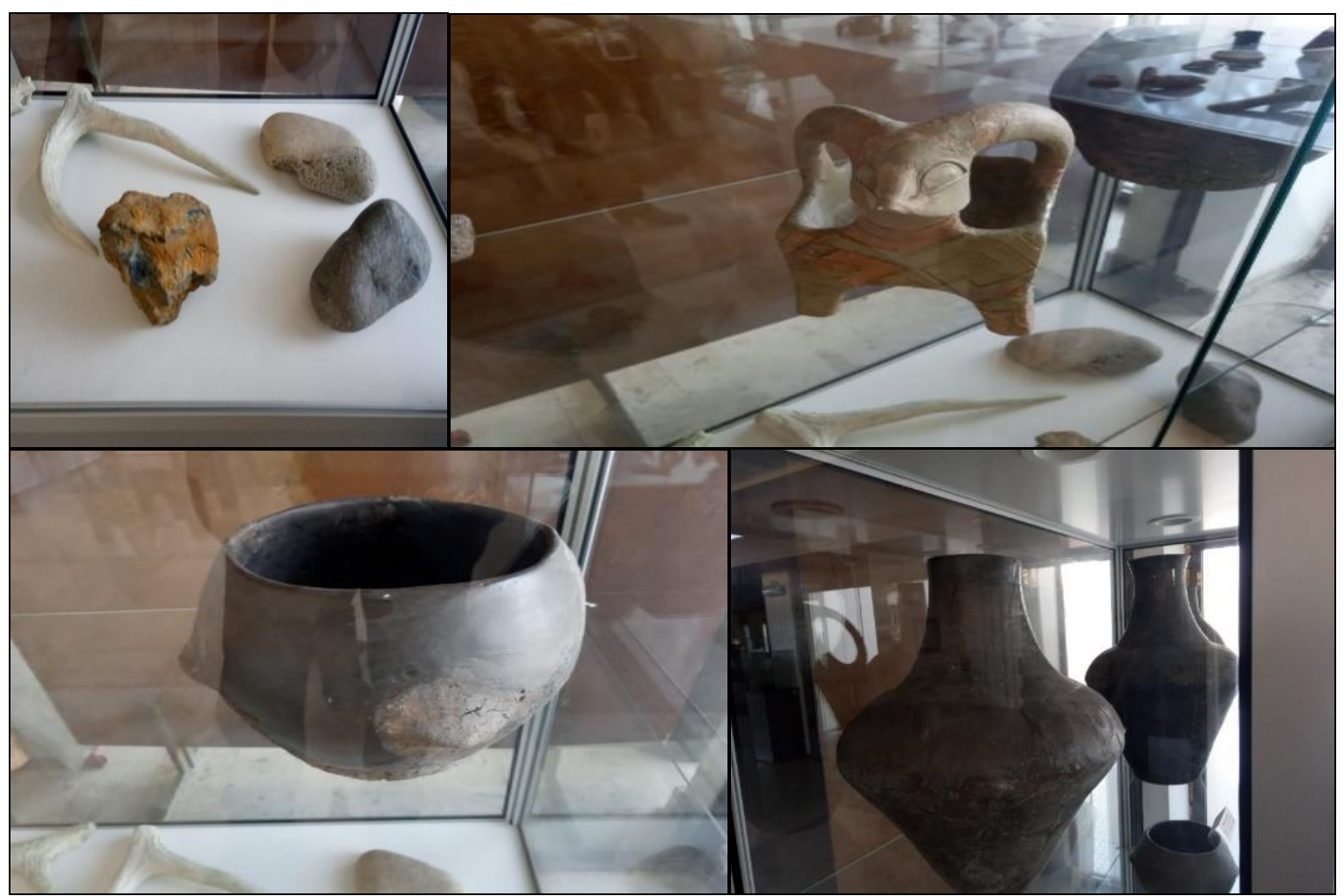

Figure 1. Some of the artifacts from the site of Rudna Glava are exhibited in the Museum of Mining and Metallurgy in Bor - upper level, from left to right: stone and bone tools, and so-called "ceramic altar", and lower level: ceramic vessels from 6-5th millennium BC 


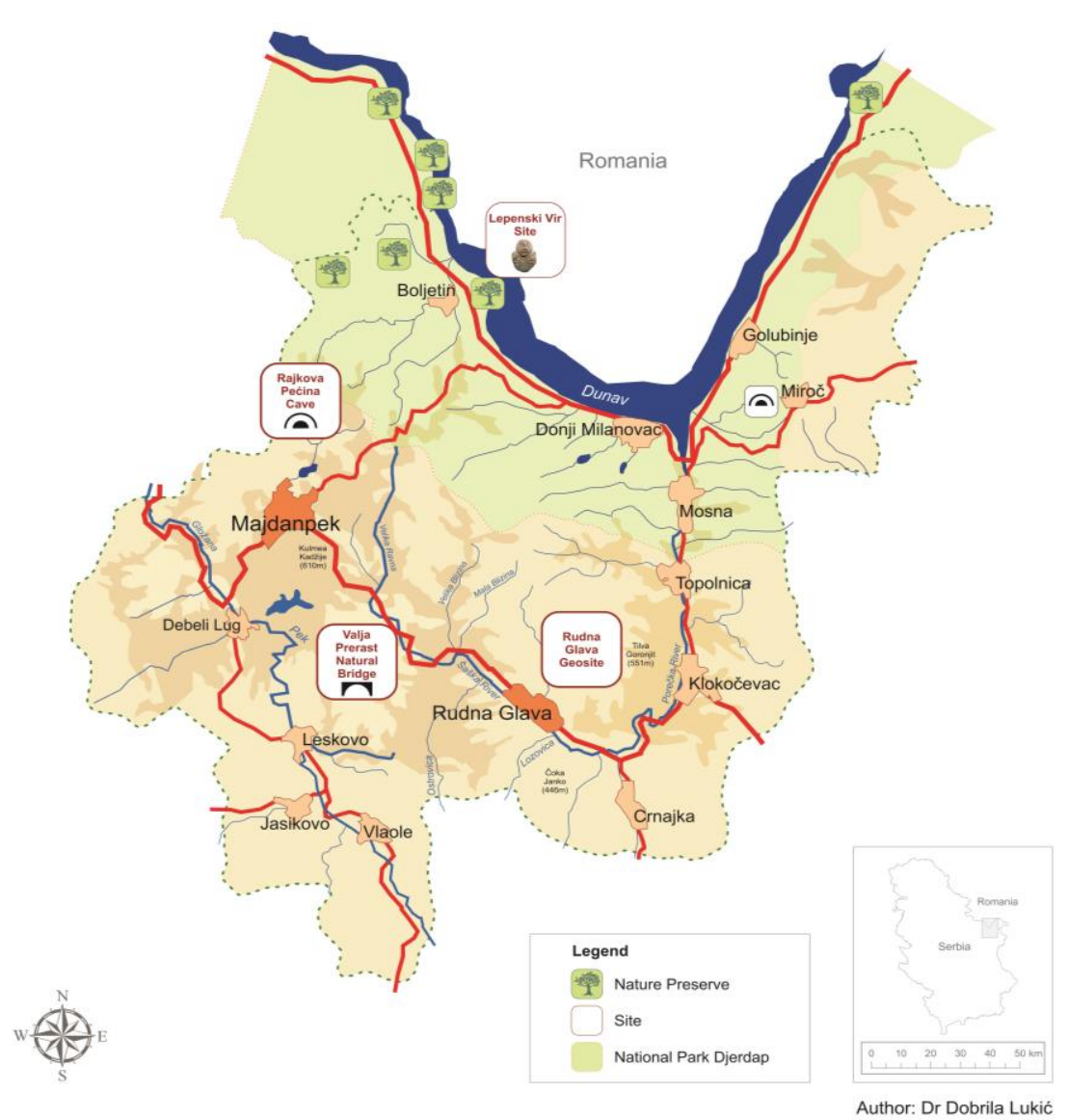

Figure 2. The map of cultural and natural potentials - the Majdanpek Municipality, Serbia

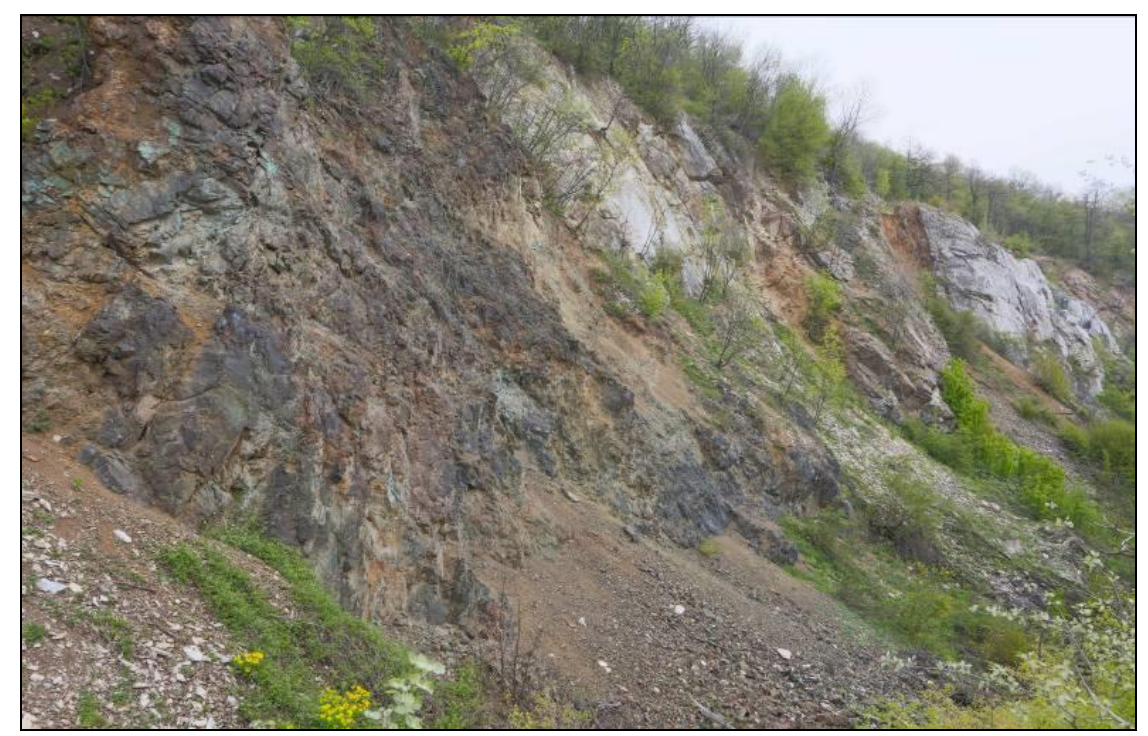

Figure 3. The observed site - view from the east (Milovanović, 2013)
Rudna Glava ore deposit was researched by Borislav Jovanović in the 60s of the last century. Namely, at the depth of about $12 \mathrm{~m}$ below the surface, the miners discovered an 'altar lamp' made of clay and decorated with deer heads which is exhibited in the museum in Negotin. This item attracted the attention of the archeologist Borislav Jovanovic and inspired by it, together with Ilija Janković, the director of the Museum of Mining and Metallurgy in Bor (the town in Eastern Serbia), he discovered the shafts and the ceramic of the Vinča culture on the slopes of Rudna Glava (Figure 1). After that, detailed archeological research of Rudna Glava site was conducted in the period between 1968 and 1986. During that period, around 40 mining shafts were discovered. Some of them were almost intact and 5 'niches' contained pottery. Tools made of stone and horns were also excavated. This site provided rich evidence of the early works in copper mines and enabled an important insight into the prehistoric mining activities in Europe. Rudna Glava is located $20 \mathrm{~km}$ southeast from Majdanpek, in Eastern Serbia (Figure 2), and magnesite ore, which this region is rich with, as well as azurite and cuprite, were excavated from this mine (Filipović, 2015).

Even though Rudna Glava is protected as cultural property, it is in a very bad state regarding the fact that it is exposed to erosions, rock slides and landslides (Figure 3 ), with no protective construction that would protect the site from further devastation. The discovered artifacts from the site are kept in the Museum of Mining and Metallurgy in Bor. Far back in 1984, Čedomir Vasić and Borislav Jovanović created a technical solution for the protection of the site in order to enable its conservation and presentation. Their solution was elaborated in 2001 by the curator of the museum in Majdanpek, Paun Durlić. The project was supposed to be realized by the institutions in Serbia - local museums, the Archeological Institute in Belgrade, the Department for the Protection of Cultural Properties in Niš, and the partner companies from Germany.

The only thing that has been done so far was the geodetic screening of the terrain in 2001, which was supposed to be the preparation for further activities. The further activities were not carried out due to the lack of finances (Filipović, 2015).

\section{METHODOLOGY}

When it comes to the methodological approach for tourist valorization of geoheritage objects, various methods are implemented in a variety of studies worldwide, including the valorization of scientific, educational, economic, conservation, and additional values (Brilha, 2016; Gorska-Zabielska, 2020), "Reynard Model" implementation (Reynard, 2008; Arora et al., 2020), a method that includes 20 criteria that assess the material value, location value, cultural value, availability and accessibility of information about the observed object (Dmytrowski and Kicinska, 2011; Ludwikowska-Kedzia and Wiatrak, 2020), qualitative approach (Aoulad-Ali et al., 2019; Mirari and Benmlih, 2020), and the GAM model (Hose, 1997; Pralong, 2005; Serrano and González-Trueba, 2005; Pereira et al., 2007; Reynard et al., 2007; Zouros, 2007; Reynard, 2008; Vujičić et 
al., 2011). So far in Serbia, the GAM model and its modified version (M-GAM) have been primarily used for tourist valorization of natural stone bridges (Antić et al., 2020), earthen pyramids (Jonić, 2018), canyons (Tomić and Božić, 2014), speleological objects (Tomić at al., 2019), mountains (Petrović et al., 2013; Vukoičić et al., 2018), rock profiles and artesian springs (Petrović et al., 2017), etc. Considering that the evaluation of Rudna Glava site for the purposes of geotourism has not been done so far, this paper aims to make a comprehensive assessment having in mind its relevant scientific, educational, and cultural value. In this respect, the Geosite Assessment Model - GAM was implemented as the most useful instrument with the goal to point to the current state of the basic and additional tourism values of the geoheritage objects which have not achieved their maximum potential yet. This provides a relatively real image of the geoheritage state based on which it is possible to plan and improve the tourist activities for the analyzed objects (Vujičić et al., 2011). This model was applied in the tourism valorization of the archeological site of Rudna Glava since the site is still rarely visited by visitors, so it was not possible to apply the advanced M-GAM model (Petrović et al., 2017; Miljković et al., 2018; Vukoičić et al., 2018), which primarily evaluates the opinion of visitors, and not only of the experts.

GAM model consists of two key indicators: main and additional values. The main values have 12 subindicators grouped into three categories: scientific-educational values (VSE), special aesthetic values (VSA), and protection (VPr). On the other hand, the additional values have 15 subindicators grouped into two categories: functional values (VFn) and tourist values (VTr). Their values range from 0 to 1 and they are: 0.00, 0.25, 0.50, 0.75, and 1.00 (Vujičić et al., 2011; Petrović et al., 2013).

$$
\mathrm{GAM}=\text { Main values }(\mathrm{VSE}+\mathrm{VSA}+\mathrm{VPr})+\text { Additional values }(\mathrm{VFn}+\mathrm{VTr})
$$

Table 1. The Main Values of the GAM model (Vujičić et al., 2011)

\begin{tabular}{|c|c|c|c|c|c|}
\hline Main indicators/subindicators & \multicolumn{5}{|c|}{ Values (0-1) } \\
\hline Value & 0 & 0.25 & 0.5 & 0.75 & 1 \\
\hline \multicolumn{6}{|l|}{ I Scientific-educational values (VSE) } \\
\hline 1. Rarity & local & regional & national & international & $\begin{array}{c}\text { a unique } \\
\text { phenomenon }\end{array}$ \\
\hline 2.Representativeness & no & low & moderate & high & the highest \\
\hline $\begin{array}{l}\text { 3.Knowledge about geoscientific } \\
\text { questions }\end{array}$ & no & local publications & regional publications & $\begin{array}{c}\text { national } \\
\text { publications }\end{array}$ & $\begin{array}{l}\text { international } \\
\text { publications }\end{array}$ \\
\hline 4.Interpretation level & no & $\begin{array}{l}\text { A moderate level of the } \\
\text { process, but difficult to } \\
\text { explain for those who } \\
\text { are not experts }\end{array}$ & $\begin{array}{l}\text { A good example of the } \\
\text { process, but difficult to } \\
\text { explain for those who } \\
\text { are not experts }\end{array}$ & $\begin{array}{l}\text { A moderate level } \\
\text { of the process, but } \\
\text { easy to explain for } \\
\text { all the visitors }\end{array}$ & $\begin{array}{c}\text { A good example } \\
\text { of the process, and } \\
\text { easy to explain for } \\
\text { all the visitors }\end{array}$ \\
\hline \multicolumn{6}{|l|}{ II Special aesthetic values (VSA) } \\
\hline $\begin{array}{l}\text { 1.Lookouts (each of them has to } \\
\text { represent the certain angle of the view } \\
\text { and be at least } 1 \mathrm{~km} \text { away from the spot) }\end{array}$ & none & 1 & 2 to 3 & 4 to 6 & More than 6 \\
\hline $\begin{array}{l}\text { 2.Area (each is quantitatively considered } \\
\text { in comparison with others) }\end{array}$ & small & - & medium & - & large \\
\hline 3.Surrounding landscape and nature & - & low & medium & high & the highest \\
\hline 4.Environment state & unsuitable & - & neutral & - & suitable \\
\hline \multicolumn{6}{|l|}{ III Protection (VPr) } \\
\hline 1.Current state & $\begin{array}{l}\text { Completely } \\
\text { damaged (as a } \\
\text { result of human } \\
\text { activities) } \\
\end{array}$ & $\begin{array}{c}\text { Greatly damaged (as a } \\
\text { result of natural } \\
\text { processes) }\end{array}$ & $\begin{array}{l}\text { Partly damaged (with } \\
\text { the preserved basic } \\
\text { geomorphologic } \\
\text { features) }\end{array}$ & Slightly damaged & Undamaged \\
\hline 2.Protection level & none & Local & Regional & National & International \\
\hline 3.Vulnerability & $\begin{array}{c}\text { Irreversible } \\
\text { (with the } \\
\text { possibility of a } \\
\text { complete loss) } \\
\end{array}$ & $\begin{array}{l}\text { High (can easily be } \\
\text { damaged) }\end{array}$ & $\begin{array}{c}\text { Medium (can be } \\
\text { damaged by natural } \\
\text { processes or human } \\
\text { activities) }\end{array}$ & $\begin{array}{c}\text { Low (can be } \\
\text { damaged only by } \\
\text { human activities) }\end{array}$ & Not existing \\
\hline 4.Suitable number of visitors & 0 & 0 to 10 & 10 to 20 & 20 to 50 & More than 50 \\
\hline
\end{tabular}

The main values (Table 1) include scientific-educational values, special aesthetic values, and protection, while the additional values (Table 2) include functional and tourism values.

Scientific-educational values:

Rarity is a very important characteristic of the geoheritage objects, and it represents the assessment of their uniqueness and particularity within the group of similar phenomena;

Representativeness describes the educational-didactic characteristics of a geoheritage object. It represents a physical presentation on the spot of its appearance and in museums and collections, the presentation in publications and media, as well as a popular presentation in school textbooks, newspapers, on television, lectures, etc.;

Knowledge about geoscientific questions represents a scientific-expert presentation in magazines, journals, and monographs;

Interpretation level is an indicator that refers to the presentation of geoheritage objects in an interesting and easy way, so that tourists can enjoy themselves and learn about it (Petrović et al., 2013). 


\section{Special aesthetic values:}

Lookouts belong to the special aesthetic values. Their larger number enables the observation of geoheritage objects and they contribute to a more impressive experience of the entire space among the tourists;

Area, surrounding landscape, and the environment state in terms of the equipment of the site are complementary values with the values of geological resources (Petrović et al., 2013).

\section{The protection includes:}

The gradient of the current state of an object measures if there is a damage on the object or not;

Protection level measures the level of protection from the local to the international level;

Vulnerability indicates the endangerment level of the geosite from natural and anthropogenic activities;

Suitable number of visitors is the allowed number of visitors on a geosite in a certain period so that no damages would occur.

\section{Functional values:}

Accessibility indicates the possibility of accessing a geosite on foot or by some means of transport;

Additional natural and anthropogenic values represent the addition to the tourism attractiveness of a geosite, where the type of area, diversity, nature preservation, the arrangement of the surrounding area, and the purpose of the area are valued;

Proximity of the outbound centers and important road networks are very important values because the number of potential visitors and the affirmation level of geosite object as a tourism destinations depend on them (Petrović et al., 2013);

Additional functional values reflect in the number of parking places, gas stations, etc.

\section{Tourism values:}

Promotion on the tourism market is a way of promotion through brochures, films, internet presentations etc.

The number of visitors within organized visits is the number of tourists who come through tourist agencies, and there is also the total number of visitors;

Proximity of visitors' centers is the distance of a geosite from visitors' centers;

Interpretative panels and tourism infrastructure, as well as the types of tourism services, accommodation, restaurant services, and a quality guide service are important because the visitors' knowledge and their overall experience of the geosite object depend on them (Petrović et al., 2013).

Table 2. The Additional Values of the GAM Model (Vujičić et al., 2011)

\begin{tabular}{|c|c|c|c|c|c|}
\hline Additional indicators/subindicators & \multicolumn{5}{|c|}{ Values (0-1) } \\
\hline Value & 0 & 0.25 & 0.5 & 0.75 & 1 \\
\hline \multicolumn{6}{|l|}{ I Functional values (VFn) } \\
\hline 1.Accessibility & Inaccessible & \begin{tabular}{|c|} 
Low (on foot with \\
special equipment \\
and an expert guide)
\end{tabular} & \begin{tabular}{|c|} 
Medium (by \\
bicycle or other \\
motor vehicle)
\end{tabular} & High (by car) & Highest (by bus) \\
\hline 2.Additional natural values & none & 1 & 2 to 3 & 4 to 6 & More than 6 \\
\hline 3.Additional anthropogenic values & none & 1 & 2 to 3 & 4 to 6 & More than 6 \\
\hline 4.Proximity of outbound centers & More than $100 \mathrm{~km}$ & 100 to $50 \mathrm{~km}$ & 50 to $25 \mathrm{~km}$ & 25 to $5 \mathrm{~km}$ & Less than $5 \mathrm{~km}$ \\
\hline 5.Proximity to important routes & none & local & regional & national & international \\
\hline 6.Additional functional values & none & small & medium & high & highest \\
\hline \multicolumn{6}{|l|}{ II Tourist values (VTr) } \\
\hline 1.Promotion & Not existing & Local & Regional & National & International \\
\hline 2.Number of visitors within organized visits & none & Less than 12 a year & 12 to 24 a year & 24 to 48 a year & More than 48 a year \\
\hline 3.Proximity of visitors' centers & More than $50 \mathrm{~km}$ & 50 to $20 \mathrm{~km}$ & 20 to $5 \mathrm{~km}$ & 5 to $1 \mathrm{~km}$ & Less than $1 \mathrm{~km}$ \\
\hline $\begin{array}{l}\text { 4.Interpretative panels (the characteristics } \\
\text { of the text and graphics, quality of the } \\
\text { material, size, adjustment to the } \\
\text { environment, etc.) }\end{array}$ & no & Low quality & Medium quality & High quality & Highest quality \\
\hline 5.Annual number of visitors & none & $\begin{array}{c}\text { Low (less than } \\
5,000)\end{array}$ & $\begin{array}{l}\text { Medium }(5,001 \\
\text { to } 10,000)\end{array}$ & $\begin{array}{l}\text { High }(10,001 \\
\text { to } 100,000) \\
\end{array}$ & $\begin{array}{c}\text { Highest (more than } \\
100,000)\end{array}$ \\
\hline $\begin{array}{l}\text { 6.Tourism infrastructure (hiking trails, rest } \\
\text { areas, toilets, waste bins, etc.) }\end{array}$ & none & Low & Medium & High & Highest \\
\hline $\begin{array}{l}\text { 7.Guide service (level of expertise, } \\
\text { knowledge of foreign language, } \\
\text { interpretative skills, etc.) }\end{array}$ & none & Low & Medium & High & Highest \\
\hline 8.Accommodation & More than $50 \mathrm{~km}$ & $25-50 \mathrm{~km}$ & $10-25 \mathrm{~km}$ & $5-10 \mathrm{~km}$ & Less than $5 \mathrm{~km}$ \\
\hline 9.Restaurant service & More than $25 \mathrm{~km}$ & $10-25 \mathrm{~km}$ & $10-5 \mathrm{~km}$ & $1-5 \mathrm{~km}$ & Less than $1 \mathrm{~km}$ \\
\hline
\end{tabular}

By adding up the results for any geoheritage object, we get its position in the GAM matrix. The matrix cells are defined in the following way and they are presented in Table 3:

$\mathrm{Z}_{11}$ - low main values and low additional values;

$\mathrm{Z}_{12}$ - low main values and medium additional values;

$\mathrm{Z}_{13}$ - low main values and high additional values; 
$\mathrm{Z}_{21}$ - medium main values and low additional values;

$\mathrm{Z}_{22}$ - medium main values and medium additional values;

$\mathrm{Z}_{23}$ - medium main values and high additional values;

$\mathrm{Z}_{31}$ - high main values and low additional values;

$Z_{32}$ - high main values and medium additional values;

$\mathrm{Z}_{33}$ - high main values and high additional values.

Table 3. GAM matrix of the calculated values

\begin{tabular}{|c|c|c|c|c|}
\hline \multirow{4}{*}{$\begin{array}{l}\text { Additional } \\
\text { values }\end{array}$} & $10.1-15$ & $\mathrm{Z}(1.3)$ & $\mathrm{Z}(2.3)$ & $\mathrm{Z}(3.3)$ \\
\hline & $5.1-10$ & $\mathrm{Z}(1.2)$ & $\mathrm{Z}(2.2)$ & $\mathrm{Z}(3.2)$ \\
\hline & $0-5$ & $\mathrm{Z}(1.1)$ & $\mathrm{Z}(2.1)$ & $\mathrm{Z}(3.1)$ \\
\hline & & $0-4$ & $4.1-8$ & $8.1-12$ \\
\hline & \multicolumn{4}{|c|}{ in valu } \\
\hline
\end{tabular}

Table 4. The sum of the main values of Rudna Glava archeological geoheritage object

\begin{tabular}{|c|c|c|c|c|c|c|c|c|c|c|c|c|}
\hline \multicolumn{10}{|c|}{ Main indicators/ subindicators } \\
\hline $\begin{array}{c}\text { I Scientific-educational } \\
\text { values (VSE) }\end{array}$ & \multicolumn{2}{|c|}{$\begin{array}{c}\text { II Special aesthetic } \\
\text { values (VSA) }\end{array}$} & \multicolumn{3}{c|}{$\begin{array}{c}\text { III Protection } \\
\text { (VPr) }\end{array}$} & Total \\
\hline 1. & 2. & 3. & 4. & 1. & 2. & 3. & 4. & 1. & 2. & 3. & 4. & \\
\hline 0.75 & 1 & 1 & 1 & 0.5 & 0.5 & 0.75 & 0 & 0.25 & 1 & 0 & 0.75 & $\mathbf{8 . 5 0}$ \\
\hline
\end{tabular}

\section{RESULTS AND DISCUSSION}

The sum of the main values for Rudna Glava archeological geoheritage object is 8.50 (Table 4). Scientific-educational values are very high, since their sum is 3.75. Rudna Glava is not the only phenomenon, but it has an international character when it comes to the rarity of the phenomenon as a subindicator because it provides an insight into the prehistoric mining activities on the territory of the whole Europe. That is why the representativeness, knowledge about geoscientific questions, and the interpretation level also achieved the highest scores. Educational-didactic characteristics of the object are very high, even though the physical presentation on the spot of the appearance is endangered by natural processes and human negligence. However, numerous artifacts discovered on this site are kept in the Museum of Mining and Metallurgy in Bor. Rudna Glava has been written about in numerous scientific and expert papers printed in domestic and international journals, while the site represents a good example of the mining processes in Eneolithic Age with the possibility of understandable description for all the visitors.

Rudna Glava may be observed from the east and from the west side at the distance of $1 \mathrm{~km}$, which contributes to a tourist's better impression of the whole area. The area of the site belongs to the medium category, while the state of the environment and of the surrounding landscape as complementary values with the site, are at a very high level. This causes the sum of special aesthetic values of Rudna Glava archeological object to be 1.75 . The current state of the object is very bad since the site is exposed to the harmful effects of the natural processes, and there is a danger of the irreversible loss of the site. So far the site has been under the protection of the state as cultural property, and is a part of Djerdap UNESCO Global Geopark, which has been in the UNESCO global network of geoparks since July 10, 2020. The project that was created by Vasić and Jovanović refers to the conservation and presentation of the site, and it relies on the organisation of the whole area and the function which a site should have and give to the potential visitors, and which comes from the conditions imposed by the terrain itself. The parking lot that would be made by a partial cutting in the hill and on the part of the plateau formed of the tailings thrown away during the modern exploitation of the mine, would be reached by the new route. The rest of the plateau space would contain the relocated traditional houses characteristic for this area.

They would contain an exhibiting area, guide service, and the site protection and maintenance service. The exhibiting setup would enable the visitors to get informed about the early Neolithic mining on Rudna Glava. From there, the plateau would be reached by the arranged paths at the bottom of the faults from which the visitors could see the spaces where the mining work was done in the early Eneolithic age, the central fault with the examined early Eneolithic shafts, as well as the Ancient gallery. From the lookout plateau, they could also reach the examined platforms of the central fault and the western platforms of the fault, where there are the shafts covered by the protective construction whose position and appearance were designed to fit the extraordinary surrounding. Below the designed construction, the technology of early Eneolithic copper mining used in Rudna Glava would be presented. After this, the visitors would be able to take a tour around the galleries and go down to the conserved shafts in the central fault. That would be the way to conserve, protect and present the site, along with remedying the consequences of erosion and denudation (http://www.heritage.gov.rs/cirilica/Download/ Saopstenja/Saopstenje-XVI1984/Saopstenje_XVI_1984_Mogucnosti_zastite _i_prezentacije_ranoeneolitskog_i_antickog_ rudnika_bakra_Rudna_Glava.pdf $\backslash$ ). The allowed number of visitors that could visit the site, which would enable to avoid the damages due to tourism activities, ranges from 20 to 50 at one instance. The sum of the subindicators related to the protection of Rudna Glava archeological geoheritage object is 2.0.

The sum of the additional values for Rudna Glava archeological geoheritage object is 4.50 (Table 5). The accessibility to the site is high, regarding the fact that it is possible to reach the site by car. Additional natural and anthropogenic tourism values as complementary values, complete the tourist offer of the site, and there are numerous special natural values in the proximity of Rudna Glava. On the territory of the municipality of Majdanpek, within which Rudna Glava archeological geoheritage object is located, there are also the following protected natural objects: Djerdap National Park, Rajkova Pećina cave, Beli Izvorac tufa reservoir, Valja Prerast natural stone bridge, and the protected cultural monuments: Lepenski Vir archeological site, the Church of the Holy Apostles Peter and Paul, the Church of St Nikola, Kapetan Miša's Mansion, and Tenkina kuća. Rudna Glava archeological geoheritage object is located $190 \mathrm{~km}$ from Belgrade, the largest outbound tourism center in Serbia, and $25 \mathrm{~km}$ from Djerdap Highway and the Danube River as an important route - Corridor VII. However, additional functional values in terms of the proximity of parking spaces, gas stations etc. are very small. The sum of the functional values for Rudna Glava archeological geoheritage object is 1.75 . 
Table 5. The sum of the additional values of Rudna Glava archeological geoheritage object

\begin{tabular}{|c|c|c|c|c|c|c|c|c|c|c|c|c|c|c|c|}
\hline \multicolumn{10}{|c|}{ Additional indicators / subindicators } \\
\hline \multicolumn{10}{|c|}{ I Functional values (VFn) } & \multicolumn{1}{|c|}{ II Tourist values (VTr) } & Total \\
\hline 1. & 2. & 3. & 4. & 5. & 6. & 1. & 2. & 3. & 4. & 5. & 6. & 7. & 8. & 9. & \\
\hline 0.75 & 1 & 0.75 & 0 & 1 & 0.25 & 0 & 0 & 0.25 & 0 & 0 & 0 & 0 & 0.25 & 0.25 & $\mathbf{4 . 5 0}$ \\
\hline
\end{tabular}

Table 6. The sum of the main and additional values of Rudna Glava archeological geoheritage object

\begin{tabular}{|c|c|c|c|}
\hline \multirow{2}{*}{$\begin{array}{c}\text { GAM } \\
\text { Geosite } \\
\text { Label }\end{array}$} & \multicolumn{3}{|c|}{ Values } \\
\cline { 2 - 4 } & Main & Additional & \\
\cline { 2 - 4 } & $\Sigma$ & $\Sigma$ & $\mathrm{Z}$ \\
\hline Rudna Glava & $\mathbf{8 . 5 0}$ & $\mathbf{4 . 5 0}$ & $\mathbf{3 . 1}$ \\
\hline
\end{tabular}

The sum of the tourism values is very low, and it is only 0.75 . This is the consequence of no existence of promotions of the site itself through brochures, films, and internet presentation. Also, there are no organized visits to the site, except the rare excursions of geosciences students. Even though it is archeologically a very important site of international significance, there is no guide service on the site, no interpretative board or panel, or any tourism infrastructure in terms of hiking trails, rest areas, toilets, waste bins, etc. The visitors' center within Lepenski Vir archeological site is at the distance of $40 \mathrm{~km}$ from Rudna Glava archeological geoheritage object. The Golden Inn Hotel in Majdanpek is categorized with 3 stars and offers its guests the maximum capacity of 136 beds in 65 accommodation units. All the rooms are equipped with a bathroom, minibar, AC unit, cable TV, and internet connection. All the rooms, as well as the suites, have a balcony or a terrace.

The hotel also includes a restaurant with 300 seats, a banquet room, VIP room, two conference halls, a coffee-bar, and a garden. The hotel is $25 \mathrm{~km}$ away from Rudna Glava. The research provided the results as a sum of the main and additional values, and, based on them, the position of Rudna Glava on the GAM matrix is - Z (3.1) (Table 6), which means that the archeological geoheritage object has high main values and low additional values.

\section{CONCLUSION}

Rudna Glava represents a rich archeological and geological heritage which exhibits the prehistoric and mining activities on the territory of Europe. The fact that Rudna Glava archeological geoheritage object is located within Djerdap UNESCO Global Geopark is of great importance since it includes the main activities oriented toward research, protection and promotion of geoheritage not only on the regional and national, but also on the international level. Also, the activities of a geopark include the promotion of both natural and cultural resources and values of the given area. Thus, a geopark becomes a unique natural laboratory and an open-air museum where geological, ecological, and civilization history of this part of southeastern Europe is presented. Through the development of geotourism, local community is stimulated and engaged; geoconservation and economic development is also carried out along with the environment protection in terms of sustainable development, while the interests of tourists are directed toward acquiring new skills and knowledge, so the popular educational programs in the field of geosciences could be updated and raised to a higher level for the whole tourist offer of the region.

Based on the tourism valorization of Rudna Glava as an object of archeological geoheritage, it has been concluded that Rudna Glava has a great tourism potential which, unfortunately, is not used. Very high scientific-educational values have been registered, whereas additional actions should be taken toward the improvement of the specific aesthetic values and the protection, which could be achieved by getting material assets for the realization of the existing project of conservation and presentation of the site. Also, it is necessary to improve the functional and tourism values.

The improvement of the functional values primarily regards the provision of a sufficient number of parking places, gas stations, rest areas, etc., that is, the additional functional values. The improvement of tourism values primarily includes the promotion of the site, posting the interpretative boards and panels, provision of adequate guide service at the site, provision of tourism infrastructure, and organisation of visits in accordance with the bearing tourist capacity of the site.

As a tourist attraction, Rudna Glava puts a focus on the market niche - cultural-educational groups, scientific and recreational tourist activities and geotours where interpretation and storytelling are essential for the tourist experience. Moreover, the endangerment of the site due to natural processes requires a strict implementation of the guidelines for the visitors' management with regards to the limitations of the bearing capacity of the site. In the future, Rudna Glava, as other similar sites, should find a balance between the tourism potential of the destination and its ability to cope with negative effects of tourism. That is why a clear strategy should be developed on how tourism will be developed on the site because there is often a gap between the real tourism potential and tourism marketing. This assessment of the potential of a geoheritage object is of great importance for the planning of sustainable tourist activities and adequate conservation actions which ensure a long-lasting protection of the site. Including Rudna Glava into various tourist programs is a long-lasting matter that needs to be observed in a wider context of the development of tourism in Djerdap UNESCO Global Geopark and in Serbia as a whole. It should be protected, repaired, and arranged in a way that it could preserve its authenticity and guarantee the competitiveness and sustainability within which geoheritage represents the primary tourism resource.

The basic recommendations based on the study's findings are the following: preservation of Rudna Glava site as a tourist attraction through restoration; protection with maximum investment attraction; rationalization of socio-economic activities and their implementation with sustainable principles; construction of tourist infrastructure and superstructure in accordance with the surrounding landscape; development of international tourism; the construction of a visitor center with museum exhibits which would stimulate scientific and cultural events in this area as well as the inclusion of archaeological geoheritage in its sustainable development; use of various tools for tourist promotion of the archeological geoheritage site; raising the awareness of the local population about the importance of geoheritage and its role in economic and social development and developing the creativity and innovation of the local population in order to develop a tourist destination; the development of geotourism would influence the progress of other branches of the local economy, including agriculture, 
crafts, various service, etc., which would create new jobs and keep young people in this area; management of this area should be an important aspect of geotourism in Serbia, because the preservation and conservation of archaeological geoheritage should be seen as a project of national importance. Further research of archeological geoheritage sites and their geotourism affirmation could be achieved by connecting the region of eastern Serbia and Djerdap UNESCO Global Geopark with the Transdanubian region of the Mehedinti plateau in Romania, which is a nature park in that country and is under state protection. Such an endeavor would require additional multidisciplinary research and projects for the sustainable development of geotourism in this part of Europe, which would achieve multicultural and scientific cooperation, and geotourism would develop as a secondary tourism product on the Serbian market.

\section{REFERENCES}

Abdelmaksoud, K.M., (2020). Geosites in the Islamic Age, Cairo-Egypt. GeoJournal of Tourism and Geosites, 32(4), $1259-1263$. https://doi.org/10.30892/gtg.32410-566

Antić, A., Tomić, N., \& Marković, S. (2020). Karst - Based Geotouris in Eastern Carphatian Serbia: Exploration and Evaluation of Natural Stone Bridges. Geoconservation Research, 3(2), 62-80. http://dx.doi.org/10.30486/gcr.2020.1903486.1023

Antonović, B. (2018). Eneolitski rudnici bakra na Balkanu. Povratak u prošlost, bakarno doba u Sjevernoj Hrvatskoj. [Eneolithic copper mines in the Balkans. A return to the past, the Copper Age in Northern Croatia]. Zagreb: Arheološki muzej u Zagrebu, Filozofski fakultet Sveučilišta u Zagrebu, Arheološki muzej Osijek.

Aoulad-Sidi-Mhend, A., Maaté, A., Amri, I., Hlila, R., Chakiri, S., Maaté, S., \& Martín, M.M. (2019). The Geological Heritage of the Talassemtane National Park and the Ghomara coast Natural Area (NW of Morocco). Geoheritage, 11, $1005-1025$. https://doi.org/10.1007/s12371-019-00347-4

Arora, K., Rajput, S. \& Anand, R.R. (2020). Geomorphosite Assessment for the Development of Scientific Geo/Tourism in Nort and Middle Andaman's, India. GeoJournal of Tourism and Geosites, 32(4), 1244-1251. https://doi.org/10.30892/gtg.32408-564

Bhinekawati, R., Nelloh, L.A.M., \& Abdurahman, O. (2020). The Analysis of Entrepreneurial Intention in Rural Area> a Case Study of Bukit Peramun Geosite in Indonesia. GeoJournal of Tourism and Geosites, 28(1), 80-94. https://doi.org/10.30892/gtg.28106-453

Borić, D. (2009). Absolute dating of metallurgical innovations in the Vinča culture of the Balkans. In T. L. Kienlin and B. W. Roberts, eds. Metals and Societies. Studies in honour of Barbara S. Ottaway, Universitätsforschungen zur Prähistorischen Archäologie, Bonn: Verlag Dr. Rudolf Habelt GmbH, 169, 191-245.

Brilha, J. (2016). Inventory and Quantitative Assessment of Geosites and Geodiversity Sites: A Review. Geoheritage, 8(2), 119-134. https://doi.org/10.1007/s12371-014-0139-3

Bujok, P., Klempa, M., Jelinek, J., Porzer, M., \& Rodriguez Gonzalez, M.A.G. (2015). Industrial Tourism in the Context of the Industrial Heritage. GeoJournal of Tourism and Geosites, 15(1), 81-93. http://gtg.webhost.uoradea.ro/PDF/GTG-1-2015/7_174_Porzer.pdf

Di Gregorio, F., Frongia, P., Piras, G., \& Forresu, R. (2014). Map of the natural and cultural heritage in the landscape of the carignano wine district of the sulcis region (SW Sardinia). GeoJournal of Tourism and Geosites, 13(1), 66-78. http://gtg.webhost. uoradea.ro/PDF/GTG-1-2014/6_144_GREGORIO.pdf

Dmytrowski, P., \& Kicińska, A. (2011). Waloryzacja geoturystyczna obiektów przyrody nieożywionej i jej znaczenie w perspektywie rozwoju geoparków [Geotourism valuation of unbiotic objects and their signification in prospect of geopark development]. Problemy Ekologii Krajobrazu, XXIX, 11-20 (in Polish).

Endere, M.L., \& Prado, J.L. (2014). Characterization and Valuation of Paleontological Heritage: A Perspective from Argentina. Geoheritage, 7(2), 137-145. https://doi.org/10.1007/s12371-014-0124-x

Filipović, B. (2015). Rudna Glava in the Foreground of Recent Overviews of the Beginnings of Copper Mining in Europe and of the Development of Archaeometallurgy. Balcanica 46, 341-347. https://dais.sanu.ac.rs/bitstream/id/19267/bitstream_19267.pdf

Goemaere, E., Demarque, S., Dreesen, R., \& Declercq, P.Y. (2015). The Geological and Cultural Heritage of the Caledonian Stavelot-Venn Massif, Belgium. Geoheritage, 8(3), 211-233. http://dx.doi.org/10.1007\%2Fs12371-015-0155-y

Gorska-Zabielska, M. (2020). The Most Valuable Erratic Boulders in the Wielkopolska Region of Western Poland and Their Potential to Promote Geotourism. GeoJournal of Tourism and Geosites, 29(2), 694-714. https://doi.org/10.30892/gtg.29225-500

Hadian, M.S.D., Suganda, B.R., Khadijah, U.L., \& Anwar, R.K. (2021). River Development as a Sustainable Geo/Tourism with a Participatory Stakeholder Approach. GeoJournal of Tourism and Geosites, 34(1), 155-163. https://doi.org/10.30892/gtg.34120-631

Hose, T.A. (1997). Geotourism - selling the earth to Europe. In: Marinos PG, Koukis GC, Tsiambaos GC, Stournaras GC (eds.) Engineering geology and the environment. A.A Balkema, Rotterdam, 2955-2960.

Jonić, V. (2018). Comparative analysis of Devil's town and Bryce canyon geosites by applying the modified geosite assessment model (MGAM). Researches Review of the Department of Geography, Tourism and Hotel Management, 47(2), 113-125. http://www.dgt.uns.ac .rs/en/homepage/zbornik-radova/zbornik-previous-issues/zbornik-volume47-2/

Jovanović, B. (1971). Metalurgija eneolitskog perioda Jugoslavije [Metallurgy of the Eneolithic period of Yugoslavia]. Belgrade: Arheološki institut.

Jovanović, B. (1978). The Oldest Copper Metallurgy in the Balkans. A Study of the Diffusion of Copper from Asia Minor to Southeastern Europe. Expedition, vol. fall, 9-17. https://www.penn.museum/documents/publications/expedition/PDFs/21-1/Jovanovic.pdf

Jovanović, B. (1982). Rudna Glava: Najstarije rudarstvo bakra na Centralnom Balkanu [Rudna Glava: The oldest copper mining in the Central Balkans]. Bor: Muzej rudarstva i metalurgije \& Belgrade: Arheološki institut.

Jovanović, B. (1986). New discoveries at Rudna Glava - the earliest shaft-and-gallery copper mine in Eastern Europe. Newsletter of the Institute for Archaeo-Metallurgical Studies (IAMS), 8, 1-2. https://www.bcin.ca/bcin/detail.app?id=116442

Jovanović, B. (2009). Beginning of the Metal Age in the Central Balkans according to the Results of the Archaeometallurgy. Journal of Mining and Metallurgy, 45(2), 143-148. https://doi.org/10.2298/JMMB0902143J

Jovanović, B., \& Ottaway, B.S. (1976). Copper mining and metallurgy in the Vinča group. Antiquity, 50, 104-113. https://doi.org/10.1017/S0003598X00070848

Kavčič, M., \& Peljhan, M. (2010). Geological heritage as an integral part of natural heritage conservation through its sustainable use in the Idrija Region (Slovenia). Geoheritage, 2(3), 137-154. http://dx.doi.org/10.1007\%2Fs12371-010-0018-5

Lazzarotti, O., (2003). Tourism and heritage. Annals of Geography, 112(629), 91-110. https://www.jstor.org/stable/23456318 
Ludwikowska-Kedzia, M., \& Wiatrak, M. (2020). The Geotourist Attractiveness of Lagowica River Valley (Holy Cross Mountains, Poland) - A Project of a Geotourist Trail. GeoJournal of Tourism and Geosites, 32(4), 1337-1346. https://doi.org/10.30892/gtg.32422-578

Matshusa, K., Thomas, P., \& Leonard, L. (2021). A Methodology for Examining Geotourism Potential at the Kruger National Park, South Africa. GeoJournal of Tourism and Geosites, 34(1), 209-217. https://doi.org/10.30892/gtg.34128-639

Miljković, Đ., Božić, S., Miljković, L., Marković, S., Lukić, T., Jovanović, M., Bjelajac, D., Vasiljević, Đ., Vujičić, M., \& Ristanović, B. (2018). Geosite Assessment Using Three Different Methods; a Comparative Study of the Krupaja and the Žagubica Springs Hydrological Heritage of Serbia. Open Geosciences, 10(1), 192-208. https://doi.org/10.1515/geo-2018-0015

Mirari, S., \& Benmlih, A. (2020). Promotion of Geotourism and Geoheritage at the Oases of Oued Noun. GeoJournal of Tourism and Geosites, 32(4), 1433-1440. https://doi.org/10.30892/gtg.32435-591

Ólafsdóttir, R., \& Dowling, R. (2014). Geotourism and geoparks - A tool for geoconservation and rural development in vulnerable environments: A case study from Iceland. (2009). Geoheritage, 6(4), 71-87. http://dx.doi.org/10.1007/s12371-013-0095-3

Paungya, N., Singtuen, V., \& Won-In, K. (2020). The Preliminary Geotourism Study in Phetchabun Province, Thailand. GeoJournal of Tourism and Geosites, 31(3), 1057-1067. https://doi.org/10.30892/gtg.31318-541

Pereira, P., Pereira, D., \& Caetano Alves, M.I. (2007). Geomorphosite assessment in Montesinho Natural Park (Portugal). Geographica Helvetica, 62(3), 159-168. http://dx.doi.org/10.5194/gh-62-159-2007

Petković, S. (2009). The Traces of Roman Metallurgy in Eastern Serbia. Journal of Mining and Metallurgy, 45(2), 187-196. https://doi.org/10.2298/JMMB0902187P

Petrović, M.D., Lukić, D.M., Radovanović, M., Vujko, A., Gajić, T., \& Vuković, D. (2017). "Urban geosites” as an alternative geotourism destination - Evidence from Belgrade. Open Geosciences, 9(1), 442-456. https://doi.org/10.1515/geo-2017-0034

Petrović, M.D., Vasiljević, D.A., Vujičić, M.D., Hose, T.A., Marković, S.B., \& Lukić, T. (2013). Global geopark and candidate Comparative analysis of Papuk Mountain geopark (Croatia) and Fruška Gora Mountain (Serbia) by using GAM model. Carpathian Journal of Earth and Environmental Sciences, 8(1), 105-116. http://www.ubm.ro/sites/CJEES/viewTopic.php?topicId=300

Pralong, J.P. (2005). A method for assessing the tourist potential and use of geomorphological sites. Géomorphologie. Relief, Processes, Environnement, 3, 189-196. https://doi.org/10.4000/geomorphologie.350

Reynard, E. (2008). Scientific Research and Tourist Promotion of Geomorphological Heritage, Supplementi di Geografia Fisica e Dinamica Quaternaria, 31, 225-230. http://www.glaciologia.it/wp- content/uploads/FullText/full_text_31_2/18_Reynard_225_230.pdf

Reynard, E., Fontana, G., Kozlik, L., \& Scapozza, C. (2007). A method for assessing „scientific” and „additional values” of geomorphosites. Geographica Helvetica, 62, 148-158. http://repository.supsi.ch/id/eprint/2160

Roberts, B.W., Thornton, C.P., \& Pigott, V.C. (2009). Development of metallurgy in Eurasia. Antiquity, 83, 1012-1022. https://doi.org/ 10.1017/S0003598X00099312

Sellier, D. (2016). A deductive method for the selection of geomorphosites: Application to Mont Ventoux (Provence, France). Geoheritage, 8(1), 15-29. https://doi.org/10.1007/s12371-015-0144-1

Serrano, E., \& González-Trueba, J.J. (2005). Assessment of geomorphosites in natural protected areas: The Picos de Europa National Park (Spain). Géomorphologie. Formes, Processus, Environnement, 3, 197-208. http://dx.doi.org/10.4000/geomorphologie.364

Tomić, N., \& Božić, S. (2014). A modified geosite assessment model (M-GAM) and its application on the Lazar Canyon area (Serbia). International Journal of Environmental Research, 8(4), 1041-1052. http://ijer.ut.ac.ir/article_798_36.html

Tomić, N., Antić, A., Marković, S.B., Đorđević, T., Zorn, M., \& Breg Valjavec, M. (2019). Exploring the potential for speleotourism development in eastern Serbia. Geoheritage, 11(2), 359-369. https://doi.org/10.1007/s12371-018-0288-x

Vujičić, M., Vasiljević, Đ.A., Marković, S.B., Hose, T.A., Lukić, T., Hadžić, O., \& Janićević, S. (2011). Preliminary geosite assessment model (GAM) and its application on Fruška Gora Mountain, potential geotourism destination of Serbia. Acta Geographica Slovenica, 51(2), 361-377. https://doi.org/10.3986/AGS51303

Vukoičić, D., Milosavljević, S., Valjarević, A., Nikolić, M., \& Srećković-Batoćanin, D. (2018). The evaluation of geosites in the territory of National park „Kopaonik” (Serbia). Open Geosciences, 10(1), 618-633. https://doi.org/10.1515/geo-2018-0049

Zouros, N.C., (2007). Geomorphosite assessment and management in protected areas of Greece. The case of the Lesvos Island coastal geomorphosites. Geographica Helvetica, 62, p. 169-180. https://doi.org/10.5194/gh-62-169-2007

http://www.heritage.gov.rs/cirilica/Download/Saopstenja/Saopstenje-XVI

1984/Saopstenje_XVI_1984_Mogucnosti_zastite_i_prezentacije_ranoeneolitskog_i_antickog_rudnika_bakra_Rudna_Glava.pdf $\backslash$

Article history: Received: 25.02.2021 Revised: 18.04.2021 Accepted: 15.06.2021 Available online: 30.06 .2021 